\title{
DINAMIKA GURU/PENDIDIK PAUD DI SURABAYA
}

\section{ABSTRAK}

\author{
Bustomi Arifin
}

Fakultas Ilmu Hukum, Universitas Narotama, Surabaya

bustomi.arifin@ narotama.ac.id

Pendidikan bagi anak usia dini merupakan unsur utama dalam tumbuh kembang optimal anak karena dianggap sebagai salah satu unsur pembentuk bagi anak usia dini dalam meningkatkan kemampuan, pola pikir, interaksi sosial dll. Unsur tersebut akan dapat berkembang dengan maksimal apabila difasilitasi dengan baik pula. Salah satu fasilitas yang dimaksudkan adalah tenaga pendidik bagi anak usia dini. Penelitian ini bertujuan untuk menelaah pentingnya standar kualifikasi pendidik anak usia dini dalam mencapai tumbuh kembang maksimal bagi anak usia dini. Penelitian ini menggunakan metode tinjauan pustaka terkait standar yang ditetapkan oleh pemerintah Indonesia melalui Kementerian Pendidikan dan Kebudayaan serta observasi tentang implementasi standar kualifikasi dan kompetensi para pendidik anak usia dini. Hasil penelitian ini menunjukkan bahwa perkembangan lembaga PAUD di Surabaya banyak mengalami kemajuan namun hal tersebut tidak diikuti oleh pemenuhan kompetensi dan kualifikasi tenaga pendidik anak usia dini yang sesuai dengan standar yang telah ditetapkan oleh pemerintah Indonesia Dinas Pendidikan dan Kebudayaan.

Kata Kunci: Pendidik Anak Usia Dini, Tumbuh Kembang, Standard Kualifikasi

\begin{abstract}
Education for early childhood children is an essential factor in regard to children development since this factor influences ability, way of thinking, social interaction and other children developments. Teacher is one of numerous tools that need to be prepared in order to achieve the main goals of education for children. The present study aims to elaborate the importance of qualification standards for early childhood children that are enacted by the Indonesian government through the Ministry of Education and Culture. The present study concludes that Surabaya is having great development concerning educational organization which focus on early childhood children. Unfortunately, this significant development does not followed by qualified teacher based on the regulation that is enacted by the government through the Ministry of Education and Culture.
\end{abstract}

Keywords: Early Childhood Teacher, Children Development, Qualification Standard 


\section{PENDAHULUAN}

Berkembangnya jumlah lembaga pendidikan anak usia di kota Surabaya menunjukkan bahwa minat masyarakat terkait pendidikan anak usia dini semakin meningkat. Masyarakat semakin menyadari pentingnya pendidikan bagi anak usia dini terkait tumbuh kembang optimal anak usia dini dalam meningkatkan kemampuan, pola pikir, interaksi sosial dll. Besarnya kepedulian masyarakat terhadap pentingnya pendidikan bagi anak usia dini mendorong pemerintah serta lembaga pendidikan swasta dalam memenuhi kebutuhan masyarakat terkait ketersediaan lembaga pendidikan yang menaungi pendidikan bagi anak usia dini. Hal ini ditandai dengan semakin tersebarnya lembaga pendidikan bagi anak usia dini (TK, KB, RA, BA, TPA, SPS) dibeberapa wilayah Surabaya yang didirikan baik oleh lembaga pendidikan swasta mau negara. Data statistik menyebutkan terdapat sekitar 2.893 lembaga pendidikan anak usia dini di kota Surabaya (Data Referensi Pendidikan, 2018). Tidak menutup kemungkinan berdirinya lembaga pendidikan bagi anak usia dini tersebut diatas didasarkan atas berbagai pertimbangan seperti segi komersial, kepedulian sosial, dan kemajuan dunia pendidikan. Segi komersial yang dimaksud adalah dimana para pendiri lembaga pendidikan anak usia dini melihat adanya sebuah peluang dengan mendirikan lembaga pendidikan anak usia dini yang bersifat komersial dengan mendirikan sebuah lembaga pendidikan anak usia dini yang memiliki fasilitas mewah serta didukung oleh Sumber Daya Manusia (tenaga pendidik) yang kompeten. Komersial dalam artian biaya pendidikan yang ditawarkan oleh lembaga pendidikan anak usia dini tersebut sesuai pula dengan fasilitas dan SDM yang disediakan. Target market yang disasar oleh lembaga pendidikan anak usia dini yang bersifat komersial umumnya berada pada level masyarakat menengah keatas. Tidak meratanya perekonomian masyarakat dibeberapa daerah termasuk kota Surabaya turut berperan serta dalam meningkatnya lembaga pendidikan anak usia dini yang bersifat non-komersial atau melihat dari segi kepedulian sosial dan kemajuan dunia pendidikan. Pemerintah Indonesia memberikan bantuan melalui program Dana Alokasi Khusus Bantuan Operasional Pendidikan (DAKBOP) Pendidikan Anak Usia Dini pada setiap daerah diseluruh wilayah Indonesia. Pemerintah pada tahun 2018 meningkatkan anggaran program tersebut yang dimana pada tahun 2017 sebesar Rp. 3,58 triliun menjadi sebesar Rp. 4,1 triliun. Peningkatan anggaran tersebut bertujuan agar seluruh anak di Indonesia dapat mengakses layanan PAUD (Sindonews, 2018). Disamping itu, banyak pula berdiri lembaga pendidikan anak usia dini swasta yang bersifat non-komersial diwilayah Surabaya menunjukkan bahwa kepedulian anggota masyarakat terhadap pendidikan anak usia dini. Tentu saja 
lembaga pendidikan yang bersifat non-komersial yang baik yang didirikan oleh pemerintah maupun swasta memiliki fasilitas serta SDM kurang memadai apabila dibandingkan dengan lembaga pendidikan anak usia dini yang bersifat komersial. Terlepas dari segi komersil maupun nonkomersil, faktor utama yang harus diperhatikan oleh lembaga pendidikan anak usia dini adalah terkait kualifikasi tenaga pendidik dalam mencapai tumbuh kembang optimal anak usia dini. Pemerintah melalui Kementerian Pendidikan dan Kebudayaan telah menetapkan standar kualifikasi tenaga pendidik anak usia dini melalui Peraturan Menteri Nomor 137 Tahun 2014 tentang Standard Nasional PAUD. Peraturan ini bertujuan untuk mencapai hasil maksimal dalam mencapai tumbuh kembang optimal anak usia dini di Indonesia. Namun pada kenyataan nya dinamika serta polemik terkait realisasi dari peraturan tersebut utamanya menyangkut kualifikasi tenaga pendidik pada beberapa lembaga anak usia dini masih menjadi kendala utama dalam dunia pendidikan anak usia dini. Senada dengan yang disampaikan Suyadi dan Maulidya Ulfah (2013:164) pada Lestari (2016) bahwa peningkatan kualitas sumber daya manusia berkaitan erat dengan tuntutan peningkatan mutu pendidikan. Dengan kata lain, mutu pendidikan anak usia dini akan dapat meningkat apabila mutu sumber daya manusia (guru/pendidik) juga ditingkatkan.

\section{METODOLOGI}

Penelitian ini menggunakan dua pendekatan sebagai metodologi yaitu tinjauan pustaka serta observasi. Pada pendekatan pertama penulis menggunakan studi pustaka tentang standar kualifikasi pendidik pada lembaga anak usia di Indonesia yang diberlakukan oleh Kementerian Pendidikan dan Kebudayaan melalui Peraturan Menteri Nomor 137 Tahun 2014 tentang Standar Nasional PAUD. Melalui permendiknas ini, penulis berusaha untuk menunjukkan serta menjabarkan peraturan pemerintah Indonesia terkait standar kualifikasi akademik dan kompetensi pendidik bagi pendidikan anak usia dini. Pendekatan kedua adalah melalui observasi terkait kondisi lembaga PAUD dikota Surabaya. Pendekatan kedua ini bertujuan menggambarkan situasi dunia pendidikan bagi anak usia dini terkait implementasi atas standar kualifikasi akademik dan kompetensi para pendidik pada lembaga pendidikan anak usia dini di kota Surabaya. Penelitian ini huga menggunakan pendekatan secara generalisasi terkait kesimpulan yang dihasilkan dimana kota Surabaya dijadikan sebagai model dalam justifikasi terkait dinamika tenaga pendidik bagi anak usia dini di Indonesia. Pendekatan generalisasi ini dipilih karena penulis menilai seluruh pendidik anak usia dini di Indonesia memiliki permasalahan serta latar belakang dinamika yang berpotensi memiliki kesamaan dengan kondisi yang terjadi di kota Surabaya. 


\section{PEMBAHASAN}

\section{- Peraturan Menteri Pendidikan dan Kebudayaan No. 137 Tahun 2014}

Pemerintah Indonesia melalui Kementrian Pendidikan dan Kebudayaan menyadari pentingnya pendidikan bagi anak usia dini dalam mencapai tumbuh kembang optimal. Kesadaran terkait pentingnya pendidikan bagi anak usia dini diwujudkan dalam bentuk Peraturan Menteri Pendidikan dan Kebudayaan No. 137 Tahun 2014 tentang Standar Nasional PAUD yang didalamnya juga mencakup standar kualifikasi akademik dan kompetensi guru pendidik bagi anak usia dini. Permendikbud ini merupakan pengembangan dari berbagai macam peraturan yang telah ditetapkan sebelumnya terkait pendidikan bagi anak usia dini yaitu: Undang-undang No. 20 Tahun 2003 Tentang Sistem Pendidikan Nasional; Undang-undang No. 14 Tahun 2005 Tentang Guru dan Dosen; Peraturan Presiden Nomor 60 Tahun 2013 tentang Pengembangan Anak Usia Dini HolistikIntegratif; dan merupakan pengganti Peraturan Menteri Pendidikan Nasional Nomor 58 Tahun 2009 Tentang Standard Pendidikan Anak Usia Dini. Berbagai peraturan yang telah ditetapkan oleh pemerintah Indonesia menunjukkan sikap kepedulian serta keseriusan pemerintah dalam menangani pendidikan bagi anak usia dini.

Permendikbud Nomor 137 Tahun 2014 tentang Standard Nasional Pendidikan Anak Usia Dini bermuatan tentang delapan standar pendidikan anak usia dini diantaranya adalah: (1) Standar Tingkat Pencapaian Perkembangan Anak; (2) Standar Isi; (3) Standar Proses; (4) Standar Penilaian; (5) Standar Pendidik dan Tenaga Kependidikan; (6) Standar Sarana dan Prasarana; (7) Standar Pengelolaan; dan (8) Standar Pembiayaan. Standar yang digunakan sebagai bahan acuan dalam membahas dinamika tenaga pendidik anak usia dini di Surabaya adalah standar tentang Pendidik dan Tenaga Kependidikan. Standard Pendidik dan Tenaga Kependidikan yang dimaksud dalam peraturan ini adalah "kriteria tentang kualifikasi akademik dan kompetensi yang dipersyaratkan bagi pendidik dan tenaga kependidikan PAUD”. Dengan kata lain, standar ini berusaha menjelaskan serta menunjukkan kepada masyarakat bahwa pendidik bagi anak usia dini harus memenuhi standar kriteria yang telah ditetapkan dalam peraturan tersebut diatas.

Pasal 24 ayat 1 Permendiknas No. 137 Tahun 2014 menyebutkan bahwa tenaga pendidik anak usia dini adalah tenaga profesional yang memiliki kewajiban tugas merencanakan, melaksanakan, melakukan proses evaluasi dan monitoring terkait hasil pembelajaran, melakukan bimbingan dalam proses pembelajaran, pengasuhan dan perlindungan dalam proses pendidikan bagi anak usia dini. Pada pasal 25 Permendiknas No. 137 Tahun 2014 ayat 1 dijelaskan tentang kualifikasi akademik daripada para guru/pendidik PAUD. Tenaga profesional (guru/pendidik PAUD) adalah mereka yang memiliki ijazah Diploma empat (D-IV) atau Sarjana (S1) dalam bidang 
pendidikan anak usia dini, dan bidang pendidikan lain yang relevan dengan sistem pendidikan anak usia dini, atau psikologis yang didapatkan dari program studi terakreditasi. Lebih lanjut, pasal ini juga menyatakan bahwa seseorang dapat menjadi guru/pendidik PAUD ketika mereka memiliki sertifikat Pendidikan Profesi Guru (PPG) yang diperoleh dari perguruan tinggi terakreditasi. Ayat 2 dari pasal 25 Permendiknas No. 137 Tahun 2014 menjelaskan tentang standar kompetensi guru/pendidik PAUD yang mencakup kompentensi dibidang pedagogik, kepribadian, sosial, dan profesional $^{1}$.

Garis besar dari Permendikbud No. 137 tahun 2014 adalah tentang standar kualifikasi kompetensi serta akademik guru/pendidik PAUD di Indonesia. Undang-Undang Republik Indonesia No. 20 Tahun 2014 menyatakan bahwa standar merupakan persyaratan teknis atau sesuatu yang dibakukan yang mana didalamnya meliputi tata cara dan metode yang disusun berdasarkan kesepakatan semua pihak/Pemerintah/keputusan internasional yang terkait dengan syarat keselamatan, keamanan, kesehatan, lingkungan hidup, perkembangan ilmu pengetahuan dan teknologi, pengalaman serta perkembangan masa kini dan masa depan guna memperoleh manfaat yang sebesar-besarnya (Badan Sertifikasi Nasional, 2014). Lebih lanjut salah satu pertimbangan pemerintah dalam menetapkan standar kualifikasi kompetensi dan akademik bagi guru/pendidik termasuk dalam pendidikan bagi anak usia dini adalah guru/pendidik harus memenuhi kualifikasi akademik dan kompetensi mengingat bahwa guru/pendidik adalah agen pembelajaran bagi anak usia dini dalam meraih tumbuh kembang optimal serta mampu mewujudkan tujuan pendidikan nasional (Marienda dkk, 2015).

\section{- Kualifikasi dan Kompetensi Guru/Pendidik PAUD Surabaya}

Perkembangan lembaga pendidikan anak usia dini yang sangat pesat di Surabaya tentu saja juga membutuhkan penyesuaian kualifikasi dan kompetensi guru/pendidik pada lembaga PAUD. Hal ini tidak lepas dari ditetapkan nya peraturan terkait standar kualifikasi dan kompetensi guru/pendidik anak usia dini oleh pemerintah melalui Kementerian Pendidikan dan Kebudayaan. Merujuk pada teori psikoanalisis yang dikemukakan oleh Sigmund Freud bahwa pengalaman pembelajaran pada anak usia dini dapat mempengaruhi dan menentukan kepribadian anak dimasa dewasa nanti (Irawan, 2015). Proses pembelajaran yang dapat mempengaruhi dan menentukan kepribadian anak usia dini dimasa yang akan datang tentu saja membutuhkan pendidik yang berkualifikasi dan kompeten. Hal tersebut yang menjadi dasar utama Kementerian Pendidikan dan Kebudayaan Indonesia dalam menetapkan peraturan terkait standar kualifikasi dan kompetensi

1 Penjabaran dari kompetensi guru/pendidik PAUD berdasarkan 25 Permendiknas No. 137 Tahun 2014 tersedia pada laman https://luk.staff.ugm.ac.id/atur/bsnp/Permendikbud137-2014StandarNasionalPAUD.pdf 
guru/pendidik anak usia dini tidak hanya dalam meraih tumbuh kembang optimal anak namun mampu mewujudkan tujuan pendidikan nasional.

Pemerintah Indonesia melalui Badan Akreditasi Nasional Pendidikan Anak Usia Dini dan Pendidikan Non-Formal (BAN-PAUD dan PNF) dalam melakukan proses monitoring, evaluasi dan pembimbingan atau yang lebih dikenal dengan sebutan akreditasi terkait mutu pendidikan bagi anak usia dini di Indonesia. Berdasarkan pada Undang-Undang No. 20 Tahun 2003 Tentang Sistem Pendidikan Nasional pasal 1 ayat 22 menyebutkan bahwa akreditasi merupakan sebuah kegiatan penilaian kelayakan program pendidikan berdasarkan pada kriteria yang telah diatur dan ditetapkan (Ban PAUD dan PNF, 2018). Akreditasi itu sendiri memiliki beberapa kriteria penilaian yang mana kompetensi dan kualifikasi guru/tenaga pendidik juga menjadi salah satu instrumen penilaian dalam proses akreditasi ${ }^{2}$.

Data statistik yang dipublikasi oleh Kementerian Pendidikan dan Kebudayaan pada laman resmi nya menyebutkan bahwa Surabaya memiliki total 2.893 lembaga pendidikan anak usia dini dengan keterangan sebagai berikut: 1.513 TK/RA (Taman Kanak-Kanak), 440 KB (Kelompok Bermain), 47 TPA (Tempat Penitipan Anak), dan 893 SPS (Satuan Paud Sejenis) $)^{3}$. Seluruh lembaga pendidikan anak usia dini tersebut tersebar pada 31 kecamatan di kota Surabaya (Data Referensi Pendidikan, 2018). Sampai pada tahun 2017, dari sekian banyak lembaga pendidikan anak usia dini yang terdapat di kota Surabaya, hanya sekitar 3,15\% atau 91 lembaga pendidikan anak usia dini yang sudah terakreditasi. Adapun detail lembaga pendidikan anak usia dini di Surabaya adalah sebagai berikut: 28 Kelompok Bermain (KB), 62 Taman Kanak-Kanak (TK/RA), 1 Tempat Penitipan Anak (TPA) (BAN PAUD dan PNF, 2018). Adapun hal yang menarik dari data diatas adalah bahwa 62 Taman Kanak-Kanak yang telah terakreditasi merupakan lembaga pendidikan anak usia dini yang dikelola oleh swasta. Data tersebut secara tidak langsung menggambarkan bahwa perlu ada perhatian khusus dari pihak pemerintah melalui Kementerian Pendidikan dan Kebudayaan serta para pengelola lembaga pendidikan anak usia dini terkait kualifikasi dan kompetensi guru/pendidik anak usia dini di Surabaya.

\section{KESIMPULAN}

Minat dan kepedulian masyarakat, pemerintah maupun pengelola lembaga pendidikan anak usia dini di Surabaya sangat besar. Hal ini dapat dilihat dari jumlah lembaga pendidikan anak usia

2 Informasi lengkap terkait kebijakan dan mekanisme akreditasi Pendidikan Anak Usia Dini dan Pendidikan NonFormal dapat dilihat pada laman https://dapo.paud-dikmas.kemdikbud.go.id/wpcontent/uploads/2018/02/Kebijakan-dan-Mekanisme-Akreditasi-PAUD-dan-PNF-Tahun-2018.pdf

3 Data statistik terkait jumlah lembaga pendidikan anak usia dini di Surabaya tersedia di laman http://referensi.data.kemdikbud.go.id/index21.php?kode $=056000 \& l e v e l=2$ 
dini (TK, KB, RA, BA, TPA, SPS) di kota Surabaya yang mencapai 2.893 lembaga pendidikan anak usia dini baik yang dikelola oleh swasta maupun negeri. Tingginya minat dan kepedulian masyarakat, pemerintah maupun pengelola lembaga PAUD terhadap pendidikan anak usia dini sayangnya masih belum diimbangi dengan penerapan standar yang ditetapkan oleh pemerintah khusus nya terkait kompetensi dan kualifikasi guru/pendidik anak usia dini.

Pemerintah melalui Kementerian Pendidikan dan Kebudayaan telah menetapkan standar kompetensi dan kualifikasi akademik guru/pendidik anak usia dini melalui peraturan Menteri Pendidikan dan Kebudayaan No. 137 Tahun 2014. Pada kenyataannya, implementasi dari peraturan tersebut khususnya terkait kompetensi dan kualifikasi akademik guru/pendidik anak usia dini bisa dikatakan masih sangat jauh dari apa yang sudah ditetapkan. Dalam penelitian ini, kota Surabaya dijadikan sebuah contoh dimana berdasarkan data terbaru Surabaya memiliki sekitar 2.893 lembaga pendidikan anak usia dini (TK, KB, RA, BA, TPA, SPS) namun hanya sekitar 3,15\% atau 91 lembaga yang telah terakreditasi oleh badan akreditasi nasional Pendidikan Anak Usia Dini dan Pendidikan Non-Formal (BAN PAUD dan PNF). BAN PAUD dan PNF dalam melakukan proses akreditasi terhadap lembaga PAUD menggunakan pendekatan 8 standar yang didasarkan pada Permendikbud Nomor 137 Tahun 2014 tentang Standard Nasional Pendidikan Anak Usia Dini yaitu: (1) Standar Tingkat Pencapaian Perkembangan Anak; (2) Standar Isi; (3) Standar Proses; (4) Standar Penilaian; (5) Standar Pendidik dan Tenaga Kependidikan; (6) Standar Sarana dan Prasarana; (7) Standar Pengelolaan; dan (8) Standar Pembiayaan (BAN PAUD dan PNF, 2018). Dapat disimpulkan bahwa salah satu faktor utama terkait minimnya lembaga PAUD di Surabaya yang terakreditasi adalah kurang nya pemenuhan standar (5) yaitu standar pendidik dan tenaga kependidikan.

Dinamika guru/pendidik anak usia dini di kota Surabaya secara tidak langsung menggambarkan kondisi yang serupa di seluruh wilayah Indonesia. Hal ini bukan tanpa alasan mengingat bahwa Surabaya merupakan kota terbesar kedua setelah ibukota Jakarta. Dinamika tersebut perlu mendapatkan perhatian khusus dari pemerintah Indonesia mengingat pentingnya pendidikan bagi anak usia dini dalam meraih tumbuh kembang optimal guna mencapai tujuan pendidikan nasional. Adapun sebagai bahan pertimbangan bagi pemerintah dalam mengatasi dinamika tersebut adalah dengan adanya peningkatan perlindungan, kesejahteraan, serta penghargaan yang memadai bagi para guru/pendidik anak usia dini. Peningkatan tersebut bertujuan untuk mendongkrak minat masyarakat pada usia produktif untuk dapat berpartisipasi dengan menjadi guru/pendidik anak usia dini yang kompeten dan memenuhi kualifikasi sesuai dengan standar yang telah ditetapkan. 


\section{DAFTAR PUSTAKA}

Badan Akreditasi Nasional Pendidikan Anak Usia Dini dan Pendidikan Non-Formal, 2018, Data Akreditasi Satuan PAUD Kota Surabaya: Rekapitulasi Akreditasi Berdasarkan Status Akreditasi, tersedia pada laman http://jendela.data.kemdikbud.go.id/banpnf/index.php/chome/rekapitulasipaudstatusa kreditasi?kode_wilayah=056000\&tahun $=$ diakses pada 07 Agustus, 2018.

Badan Akreditasi Nasional Pendidikan Anak Usia Dini dan Pendidikan Non-Formal, 2018, Kebijakan Akreditasi Pendidikan Anak Usia Dini dan Pendidikan Non-Formal 2018, tersedia pada laman https://www.banpaudpnf.or.id/upload/downloadcenter/Paparan\%20Ketua\%20BAN\%20PAUD\%20dan\%20PNF\%20\%20Kebijakan\%20Akredit_1519387147.pdf diakses pada 07 Agustus, 2018.

Badan Seritifikasi Nasional, 2014, Undang-Undang Republik Indonesia Nomor 20 Tahun 2014 tentang Standarisasi dan Penilaian Kesesuaian, tersedia pada laman: http://www.bsn.go.id/uploads/download/UU20_TAHUN_2014_TENTANG_SPK1.pdf diakses pada 23 Juli, 2018.

Data Referensi Pendidikan, 2018, Data Referensi: Jumlah Data Satuan Pendidikan (Sekolah) Anak Usia Dini per Kabupaten/Kota: Kota Surabaya, Kementrian Pendidikan dan Kebudayaan, tersedia pada laman http://referensi.data.kemdikbud.go.id/index21.php diakses pada 20 Juli, 2018.

Irawan, Eka Nova, 2015, Buku Pintar Pemikiran Tokoh-Tokoh Psikologi dari Klasik sampai Modern: Biografi, Gagasan, dan Pengaruh Terhadap Dunia, Yogyakarta: IRCiSoD.

Lestari, Sri, 2016, Hubungan Antara Kualifikasi Akademik Guru dengan Pengelolaan Kelas di Taman Kanak-Kanak Se-Kecamatan Gemolong, Isu-isu Kontemporer Sains, Lingkungan, dan Inovasi Pembelajarannya, Seminar Nasional Pendidikan dan Sainstek, Universitas Muhammadiyah Surakarta tersedia pada laman: https://publikasiilmiah.ums.ac.id/bitstream/handle/11617/8057/159.pdf?sequence=1 diakses pada 22 Juli, 2018.

Marienda, Winda, Moch. Zainudin, Eva Nuriyah H., 2015, Kompetensi dan Profesionalisme Guru Pendidikan Anak Usia Dini, Prosiding Penelitian dan Pengabdian Kepada Masyarakat, Vol. 2 No. 2 Hal. 147-156 tersedia pada laman: http://jurnal.unpad.ac.id/prosiding/article/view/13271/6110 diakses pada $23 \mathrm{Juli}$, 2018. 
Salinan Peraturan Menteri Pendidikan dan Kebudayaan Nomor 137, 2014, Standard Nasional Pendidikan Anak Usia Dini, tersedia pada laman: https://luk.staff.ugm.ac.id/atur/bsnp/Permendikbud137-

2014StandarNasionalPAUD.pdf diakses pada 22 Juli, 2018.

Sindonews, 2018, Bantuan Operasional PAUD Naik Jadi Rp. 4,1 Triliun, Koran Sindo, terbit pertama kali pada Kamis 8 Februari, 2018, tersedia pada laman https://nasional.sindonews.com/read/1280381/144/bantuan-operasional-paud-naikjadi-rp41-triliun-1518063328 diakses pada 07 Agustus, 2018.

Suyadi dan Maulidya Ulfah. 2013, Konsep Dasar PAUD, Bandung: PT. Remaja Rosdakarya. 